$10 / 18-94 \mathrm{gSD}$

SANDIA REPORT

SAND93-2450 - UC- 2070
Unlimited Release

Printed September 1994

\title{
A Formal Expert Judgment Procedure for Performance Assessments of the Waste Isolation Pilot Plant
}

Kathleen M. Trauth, Robert V. Guzowski, Stephen C. Hora

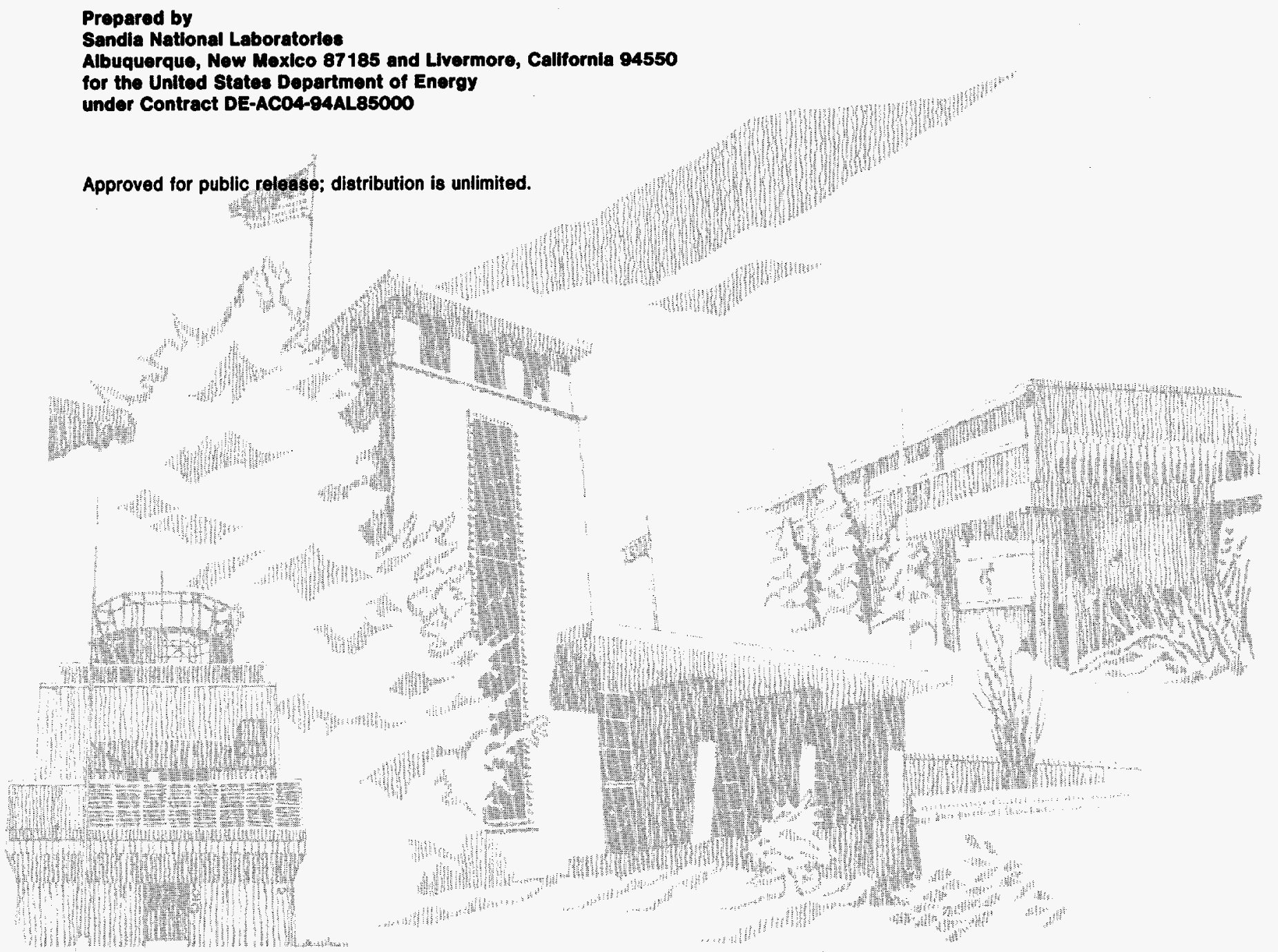


Issued by Sandia National Laboratories, operated for the United States Department of Energy by Sandia Corporation.

NOTICE: This report was prepared as an account of work sponsored by an agency of the United States Government. Neither the United States Government nor any agency thereof, nor any of their employees, nor any of their contractors, subcontractors, or their employees, makes any warranty, express or implied, or assumes any legal liability or responsibility for the accuracy, completeness, or usefulness of any information, apparatus, product, or process disclosed, or represents that its use would not infringe privately owned rights. Reference herein to any specific commercial product, process, or service by trade name, trademark, manufacturer, or otherwise, does not necessarily constitute or imply its endorsement, recommendation, or favoring by the United States Government, any agency thereof or any of their contractors or subcontractors. The views and opinions expressed herein do not necessarily state or reflect those of the United States Government, any agency thereof or 'any of their contractors.

Printed in the United States of American. This report has been reproduced directly from the best available copy.

Available to DOE and DOE contractors from

Office of Scientific and Technical Information

PO Box 62

Oak Ridge, TN 37831

Prices available from (615) 576-8401, FTS 626-8401

Available to the public from

National Technical Information Service

US Department of Commerce

5285 Port Royal RD

Springfield, VA 22161

NTIS price codes

Printed copy: A03

Microfiche copy: A06 


\section{DISCLAIMER}

Portions of this document may be illegible in electronic image products. Images are produced from the best available original document. 


\title{
A FORMAL EXPERT JUDGMENT PROCEDURE FOR PERFORMANCE ASSESSMENTS OF THE WASTE ISOLATION PILOT PLANT
}

\author{
Kathleen M. Trauth \\ Sandia National Laboratories \\ P.O. Box 5800 \\ Albuquerque, NM $87185-1328$ \\ Robert V. Guzowski \\ Science Applications International \\ Corporation \\ 2109 Air Park Rd SE \\ Albuquerque, NM $87185-1328$ \\ Stephen C. Hora \\ University of Hawaii at Hilo \\ Business Administration \& \\ Economics Division \\ Hilo, HI 96720-4091
}

\begin{abstract}
The Waste Isolation Pilot Plant (WIPP) is an experimental facility located in southeastern New Mexico. It has been designed to determine the feasibility of the geologic disposal of defense-generated transuranic waste in a deep bedded-salt formation. The WIPP was also designed for disposal and will operate in that capacity if approved. The WIPP Performance Assessment Department at Sandia National Laboratories has been conducting analyses to assess the long-term performance of the WIPP. These analyses sometimes require the use of expert judgment. This Department has convened several expert-judgment panels and from that experience has developed an internal qualityassurance procedure to guide the formal elicitation of expert judgment. This protocol is based on the principles found in the decision-analysis literature.
\end{abstract}




\section{ACKNOWLEDGEMENTS}

The authors would like to thank Sharla G. Bertram (SNL) and Leo S. Gomez (SNL) for reviewing this paper and offering many useful suggestions. The authors would also like to thank Faith Puffer (Tech Reps, Inc.) for her editorial support.

This work was performed at Sandia National Laboratories (and is documented as SAND93-2450C) which is supported by the U.S. Department of Energy under contract DE-AC04-94AL85000. 


\section{PREFACE}

This SAND report is a reproduction of the identically titled paper published in:

American Nuclear Society and American Society of Civil Engineers. 1994. High Level Radioactive Waste Management; Proceedings of the Fifth Annual International Conference, Las Vegas, Nevada, May 22-26, 1994. American Nuclear Society, LaGrange, IL: American Society of Civil Engineers, New York, NY. 



\section{INTRODUCTION}

The purpose of this paper is to discuss some of the lessons learned about the elicitation of expert judgment. These lessons are presented in the context of the Waste Isolation Pilot Plant (WIPP) Performance Assessment Department's experience with analyses of a proposed nuclear waste disposal facility.

The goal of nuclear-waste disposal is to isolate the waste for a sufficiently long period of time so that the radioactivity does not pose an unacceptable threat to humans. Since the beginning of the nuclear age, defense-related projects have generated waste contaminated with radionuclides as a byproduct of the development, manufacture, and decommissioning of nuclear devices. Some of this waste contains radionuclides heavier than uranium. This waste is referred to as transuranic (TRU) waste.

The WIPP, which is located in southeastern New Mexico, contains a test facility for investigating whether the characteristics of the location are suitable for the disposal of TRU waste. The WIPP, also a proposed disposal facility, will be located at a depth of 2,150 feet and within a bedded-salt unit (the Salado Formation). If the WIPP can be shown to comply with the appropriate federal regulations, a section of the facility not used for testing will become a disposal facility for the TRU waste.

\section{A. The EPA Standard}

One of the federal regulations with which the WIPP must comply is the U.S. Environmental Protection Agency's (EPA's) Environmental Standards for the Management and Disposal of Spent Nuclear Fuel, HighLevel and Transuranic Radioactive Wastes (40 CFR 191), ${ }^{1,2}$ hereinafter referred to as the Standard. The Containment Requirements within the Standard set probabilistic performance requirements that are to be addressed by conducting performance assessments. These assessments are to consider the 10,000 years after closure of the disposal facility. The Standard also mandates the implementation of Assurance Requirements to account for some of the uncertainty associated with performance assessments covering 10,000 years. These performance assessments are 10,000-year simulations of performance carried out on computers using models of the disposal system. Sandia National Laboratories (SNL) is the U.S. Department of Energy's scientific advisor for the WIPP and is conducting the performance assessments.

\section{B. Experience with Expert Panels}

Several formal expert-judgment panels have been convened to support the WIPP Project, both in conducting performance assessments and in addressing the Assurance Requirements. The first panel, the Future HumanIntrusion Panel ${ }^{3}$ (Futures Panel), was convened to identify possible modes of human intrusion over the 10,000-year regulatory period and to estimate the frequencies of such intrusions. The second panel, the Marker-Development Panel $^{4}$ (Markers Panel) was convened to address the need for permanent, passive markers to communicate the location and nature of the wastes proposed to be disposed of in the WIPP. The requirement to mark the disposal site is found in the Assurance Requirements. In addition, the effectiveness of markers in deterring inadvertent human intrusion into the WIPP is pertinent to the Containment Requirements. Because human intrusion would create potential pathways for radionuclides to reach the accessible environment, the Standard states that credit may be taken for such deterrence in the calculations.

Two additional panels were convened to supply interim probability distributions for parameters used in the performance assessments. The Source Term Expert Panel ${ }^{5}$ (STEP) provided probability distribution functions (pdfs) of the concentrations of radionuclides that might be expected in brines within the WIPP disposal rooms, given the potential environmental conditions within the rooms. A pdf represents the values that a fixed, but unknown, 
variable may be expected to assume and the corresponding probabilities of occurrence of the values. The Retardation Expert Panel ${ }^{5}$ (REP) provided pdfs of the distribution coefficients $\left(\mathrm{K}_{\mathrm{d}} \mathrm{s}\right)$ that may be expected in a water-bearing formation above the repository level, the Culebra Dolomite, that may act as a pathway for radionuclide transport to the accessible environment. These $K_{d} s$ indicate the extent to which the natural properties of the Culebra Dolomite retard the transport of radionuclides in ground water.

\section{EXPERT JUDGMENT}

An incomplete understanding of expert judgment may cause some individuals to question the appropriateness of its use in the context of performance assessments for a nuclear waste disposal system.

Professional judgment is implicit in scientific investigations. The development of a conceptual model to describe a natural phenomenon requires judgment to examine the current state of knowledge and to produce a coherent model of the behavior of a natural system. Judgment is required in developing mathematical and computational models to represent conceptual models. Before data are ever collected from an experiment, judgment is used in developing the hypothesis to be evaluated, in establishing the experimental conditions, and in selecting data-collection methods and equipment. Experimental data require interpretation for appropriate use in computational models.

Expert judgment is the best professional opinion of experts in a particular field. It is used to synthesize what is known (existing data) to provide the required information for a particular application. Judgment explicitly elicited from an expert panel is not a substitute for measured data, but is used to examine and synthesize whatever data exist (however abundant or sparse, under whatever experimental conditions they were collected) to provide the required information. Measured data from appropriate, practical experiments performed in a timely manner are always preferred. The extent to which directly applicable data exist and to which a phenomenon is understood dictates the extent to which judgment must be used to provide the required information. Elicited expert judgment may be appropriate and necessary where data are sparse or nonexistent, where data were collected for other applications, or where data are conflicting. For subjects where a great deal of directly applicable data exist and the phenomenon is well understood, elicited judgment may not be required to provide the necessary information (e.g., data may be analyzed by statistical techniques). The appropriate use of elicited expert judgment must be evaluated on a case-by-case basis and is driven by the individual circumstances.

Data may be collected through measurements or observations, under experimental or natural conditions. Information may be defined as data interpreted and used for a specific application. Categorical exclusion from consideration of all pertinent data collected for other purposes would not be appropriate. Data from other studies should be evaluated for applicability, and excluded or considered as appropriate.

When alternative sources of information--models and data--are available but conflict, the elicited judgments of experts may be the preferred method for integrating the data into a single probability distribution. Experts may be able to assess the uncertainty inherent in the various sources of information and, additionally, may be able to make adjustments to account for biases in the data. Expert elicitation, therefore, may provide a "calibrating" mechanism to account for differences in applications, environments, and other factors.

As an example, many data exist about the durability of monuments over time--how they have weathered natural and human assaults. All of this should be evaluated in designing the required markers for a repository, even though the data were not collected in a 
form that will directly indicate marker types. It is appropriate to elicit expert judgment to evaluate the existing data collected for archaeological or materials science purposes, and synthesize these data to develop design guidelines and estimate durability.

Another example is the need for a probability distribution of a parameter for use in the probabilistic calculations for preliminary performance assessments. Data exist on the solubility of particular radionuclides under specific environmental conditions. The information required is a probability distribution of the solubility of a radionuclide when there is uncertainty about the specific environmental conditions that will exist in the repository over time. An examination of all the available data may allow judgments about the impact that various uncertainties will have on the solubility.

Concerns have been expressed regarding the interpretations of the findings of the experts who examined future societies. ${ }^{3}$ A concern is that no one can tell the future. This is, of course, correct. What is not properly understood, however, is that the experts' role is not to identify what the future will be but to identify a variety of alternative futures that might be applied to efforts to develop effective institutional controls. A discussion of how frequently future societies might be taking actions that could intrude upon the WIPP can be utilized to determine how to implement EPA's guidance that exploratory drilling for resources is the most severe intrusive event that must be examined for compliance.

The evaluation of data and information for the purpose of policy and decision making has led to the development of formal methods for the collection of expert judgment through the elicitation of probabilities. ${ }^{6,7,8,9}$ These techniques have been applied to acquire information for use in the performance assessment of the WIPP through a formal "protocol" developed and implemented by the WIPP Performance Assessment Department at Sandia National Laboratories. ${ }^{10}$ This protocol will be called the Sandia/WIPP protocol. The techniques invoked by the protocol are those described in the literature, while the actual implementation of the techniques is conducted in a fashion that responds to the particular requirements of a nuclear-waste disposal project.

\section{WHEN FORMAL EXPERT JUDGMENT IS USED FOR THE WIPP PROJECT}

Informal expert judgments are used in most stages of performance assessments. A formal approach to the use of expert judgment is required when (1) an issue is of particular interest or sensitivity to policy makers, scientific groups, or the public, or (2) previous assessments have shown a particular parameter to greatly influence the results; and (i) alternate sources of information, data, and models are currently unavailable or are not practical to obtain, or (ii) the required data or information are not obtainable by any means other than expert judgment (e.g., future states of society).

The issues selected by the previous criteria should be addressed by an external panel of experts in consultation with staff scientists. Acceptance by the public and oversight groups is enhanced when independent experts arrive at positions even though the same judgments might be rendered by staff scientists also involved in the process. This trust and acceptance is an important aspect of expert panels.

\section{THE IMPORTANCE OF AN ESTABLISHED PROCEDURE}

A documented, established procedure for eliciting expert judgment is an aid both in maintaining the quality of the process and in supporting internal and external reviews of the process.

The Sandia/WIPP protocol was developed from a procedure that had been developed and reported in the 
decision analysis literature and with the cooperation/input from a consultant from the discipline of decision analysis. Through several expert judgment panels, the Sandia Performance Assessment Department gained insights into the topics that were important to address in an internal procedure in order to maintain the quality of the process. The procedure can continue to develop over time, as warranted, with changes implemented in subsequent uses of expert judgment.

The organized, documented procedure allows reviewers to reconstruct the logic and the events involved in the use of expert judgment. The availability of such documentation supports a better understanding and acceptance of what was undertaken. In addition, discussions in terms of principles rather than in terms of the individual outcomes are more efficient.

\section{ISSUE STATEMENT}

The development of a comprehensive but concise issue statement is fundamental to the successful elicitation of expert judgment. The issue statement precisely defines what must be addressed by the expert(s) and the format in which the judgment(s) must be presented. The development of the issue statement also plays a major role in identifying the types of experts and/or the fields of expertise to be included for eliciting expert judgment.

Issue statements are difficult to develop, and they are evolutionary. Words and phrases can mean different things to different individuals. In addition, the components of an issue may be different for persons with different perspectives. Because of possible differences in interpretations, draft issue statements are best developed as a collaborative effort rather than by a single individual. Numerous iterations of the issue statement are the rule rather than the exception.

The evolutionary nature of issue-statement development continues once the statement is presented to the experts. Experts will introduce additional perspectives and identify additional ambiguities in wording, issue decomposition, and response formats that must be resolved before unambiguous expert judgments can be obtained. The variety of perspectives and ambiguities are especially acute for multidisciplinary panels.

For example, the Markers Panel modified the issue statement by eliminating the partial focus on individual markers, and emphasizing the interdependentsystems approach they believed was crucial to long-term communication of information. The STEP also modified their issue statement after judging that sufficient related data did not exist to create pdfs for the concentrations of colloids in brine.

\section{EXPERT IDENTIFICATION AND SELECTION}

\section{A. Criteria for Selection}

Careful selection of the expert-panel members will ensure that a panel is convened that includes individuals with the appropriate qualifications and a willingness to participate fully in the expert-judgment process.

The issue(s) to be addressed by the panel determine the disciplines that must be represented, as well as the experience that is required. This connection between the issues and the disciplines is operative whether a panel is being selected from among chemists to provide required information about the solubility of radionuclides in brines or whether a panel is being formed from individuals in the disparate disciplines pertinent to the development of communication markers for a repository. In general, the criteria for inclusion as a nominee for an expert judgment panel revolve around recognized expertise in the area(s) pertinent to the issue. Obtaining an appropriate list of nominees may require different strategies depending on the issue to be addressed. For the STEP, initial nominations were sought from scientists at 
Sandia, members of a Performance Assessment Peer Review Panel, and members of the National Academy of Sciences WIPP Review Panel. For the Futures and Markers Panels, the areas of expertise thought to be pertinent were so large (the issues of future societies and markers), that the Project solicited nominations from professional societ-ies, technical journals, government organizations, and public interest groups. Initial nominees also nominated other individuals with whose expertise they were familiar.

It is also important to nominate individuals representing the spectrum of thought on a topic, if there may be different approaches or paradigms. As an example, when soliciting nominees for the Futures and Markers Panels, organizations such as the League of Women Voters, the Sierra Club, and other environmental groups were solicited for nominees in order that individuals with potentially diverse or opposing views could be considered for inclusion. For example, the Futures Panel included an individual from the Natural Resources Defense Council (NRDC), who was lead attorney in $N R D C$ v. EPA, ${ }^{11}$ the 1987 court case that resulted in the remand of the Standard. Individuals with differing views on the appropriateness of nuclear weapons and nuclear power were also represented on the Markers Panel.

Also required for an effective panel are members who understand and accept the constraints of the expertjudgment elicitation process. A constraint may be considered to be an aspect of the process with which some individuals may not be totally comfortable, but which is required. For example, an expert may not be comfortable in making judgments based on incomplete data, but the information may be necessary even if the experiments are still underway or cannot completely answer all questions. Another example of a constraint is that while an expert may not be familiar with expressing his or her judgments as probabilities or pdfs, the Standard requires a probabilistic performance assessment. The members of the
REP recognized the incompleteness of the existing data (existing data were produced from batch rather than field experiments, ${ }^{12}$ additional experiments were being planned, etc.) but worked to address the issue with the available data because interim pdfs for $\mathrm{K}_{\mathrm{d}} \mathrm{s}$ were needed for the preliminary performance assessments. Similarly, a few members of the Futures and Markers Panels had reservations about the advisability of nuclear weapons and nuclear power, and about the appropriateness of EPA regulations, yet they worked diligently to address the issues as best they could.

\section{B. Selection Advisory Committee}

A selection advisory committee (SAC) can serve the process by ranking the qualifications of the nominees and suggesting a final composition that covers all the required disciplines and subdisciplines. Whenever possible, the pertinent disciplines should be represented on the SAC. A SAC is suggested not only to establish the highest quality panel, but also for the independence they bring to the process.

\section{TRAINING}

Training is provided for the experts in two distinct areas so that the panel members have access to the information necessary to perform their tasks. The first area of training consists of a series of presentations related to the topics of the WIPP, the EPA Standard, performance assessments, and previous and ongoing characterization studies. The second area of training consists of presentations relating to the topic of expert judgment in general and to the elicitation of expert judgments.

\section{A. Orientation to the Project}

These presentations related specifically to the Project set the stage for the context in which the expert judgment is required. It is important that the panel 
members understand the requirements of the Standard for probabilistic performance assessments and thus the need for pdfs for parameter values. Such training can also indicate why certain parameters are of greater importance and are subjected to the formal expert-judgment elicitation process. Training also explains the need to address inadvertent human intrusion into the WIPP and requirements for long-term passive markers for the repository.

Training is provided by staff members who are available to answer questions during an initial informational meeting and during the subsequent panel deliberations. This interaction ensures that all applicable Project data are available to the panel. The insights provided by the training can feed back into the development of the issue statement.

The training for the Futures and Markers Panels included a tour of the WIPP and surrounding area.

\section{B. Elicitation Training}

The elicitation process is more than just the application of probability assessment tools to the judgments of experts. The experts must prepare and be prepared for the experience. Often, experts in a field such as a physical science may not be effective in expressing their beliefs in the form of probabilities or pdfs. ${ }^{13,14}$ Training the experts in forming these judgments is an important step in the Sandia/WIPP protocol.

This training has multiple objectives. One is previewing the process including how the experts' judgments will be used. Other objectives are to instill confidence in the experts not only so that they can express beliefs as probabilities and pdfs, but also because lack of confidence in the process may undermine the effort.

Experts may object to the formal elicitation and encoding of judgments into probabilities and pdfs because they believe "opinion" is being substituted for "objective" scientific research. However, the experts' role is not creating knowledge, but is instead synthesizing disparate, incomplete, or conflicting sources of information to produce an integrated picture. Experts who appreciate their role from this perspective are likely to be cooperative.

The fundamental objective of elicitation training is to help the experts accurately express their beliefs as probabilities and pdfs. Training introduces experts to the tasks they must perform. It also identifies their potential biases and provides practice in controlling them. Although practice may not lead to perfect elicitation, evidence shows that practice improves elicitation. ${ }^{14}$

\section{ORGANIZING THE EXPERTS}

There are alternative approaches to organizing a group of experts. These approaches vary with respect to the scope of the issues being addressed, the amount and type of interaction among the experts, the amount of redundancy, and the role of the experts in defining objectives. The Sandia/WIPP protocol employs multiple experts and allows for their organization to be based on the dictates of the issue under consideration.

The simplest organization is experts working in isolation from each other. When there are several experts addressing the same issues, redundancy is useful because multiple experts will have alternative viewpoints thereby increasing the potential for describing uncertainty. Alternatively, panels may be organized in which experts work together sharing information and approaches to the issues.

Another strategy for the analysis of complex issues involves multi-disciplinary teams of experts. This approach is relevant when the issue to be addressed is difficult to analyze or decompose into a series of smaller, independent or conditional issues. Multidisciplinary teams 
were used for the Futures and Markers Panels.

Once the panel of experts has been organized, their efforts must also be organized. Panels convened to date participated in an initial informational meeting where the issue statement is discussed and the training takes place. The initial meeting is followed by a work period during which the experts consider the issue statement. The actual elicitation of information occurs during the second meeting.

\section{ELICITATION OF INFORMATION}

The information that is elicited from the experts may be in several different forms: qualitative recommendations or assessments, pdfs that describe parameter values, and probabilities of particular events or situations.

\section{A. Qualitative Information}

The Sandia/WIPP protocol is flexible enough to allow the collection of a broad range of qualitative information. The Futures Panel was asked to develop descriptions of logically possible future societies and possible modes of intrusion associated with those futures. The Markers Panel was asked to develop preliminary marker descriptions that would communicate the location and danger of the waste in the repository and deter inadvertent human intrusion. Experts could also be asked about subjects as diverse as conceptual models of the behavior of natural systems or the appropriateness of modeling assumptions for the performance assessments.

Qualitative information is an important product of expert-judgment elicitation. As the WIPP continues to develop as a compliance-oriented project, and as there is a desire for an external review of various aspects of the performance assessments, qualitative expert judgment may assume a larger role.

\section{B. Quantitative Information}

The procedures for the elicitation of probabilities and pdfs are well established and can be found in decision analysis and psychology. ${ }^{13,7}$ Successful elicitation is usually accomplished through the use of specialists, sometimes termed normative analysts, from the fields of probability assessment and decision analysis. ${ }^{15}$

One useful design for elicitation is an assessment team working with one expert. ${ }^{6}$ The team members might include a normative analyst who handles the elicitation, a staff analyst who is familiar with the subject area and assists in the communication between the normative analyst and the expert, and a person responsible for documenting the session. For the panels convened to date, elicitation teams included a normative analyst and a staff analyst, but no documentarian.

The elicitation session normally takes place under the control of the normative analyst. The expert is first questioned about the fundamental way he or she has analyzed or decomposed the issue. If the question has been decomposed by the expert, then the decomposition provides the starting point for the discussion. The normative analyst has three goals: to extract the rationales for judgments; to quantify the judgments; and to assist the expert in making the elicited information accurately reflect the expert's knowledge. Reaching these goals requires a good deal of interaction between expert and normative analyst; the former is often challenged to justify his or her beliefs. Each aspect of the elicitation is approached from multiple viewpoints to reveal and resolve inconsistencies.

Care must be taken that the normative analyst and staff analyst share a common understanding of the questions being addressed. In particular, if several assessment teams are working simultaneously, some supervision is needed to ensure the consistency of their efforts. In the study of future societies, some differences among the four teams can be accounted for by the 
approaches used by the normative analysts.

Several elicitation techniques are used in the Sandia/WIPP protocol in a single assessment session to facilitate cross and consistency checks. When assessing continuous distributions, for example, direct elicitation of interval probabilities and interval bisection, the process of dividing successive intervals into subintervals of equal probability, can be used together. ${ }^{16}$ The analyst guiding the elicitation will ask questions that permit comparisons of probabilities. When inconsistencies are found, the specialist will inform the expert of the incompatibility of the probabilities and assist in modifying the assessments and reconciling the differences.

Complex problems may be decomposed into a number of smaller issues. The principle behind decomposition is that better quality probabilities and pdfs can be obtained when the assessment tasks are easier. There is an increasing amount of empirical evidence supporting this principle. ${ }^{17,18}$ One decomposition tool is the "influence diagram". ${ }^{19}$ An influence diagram is a graphical representation showing the interactions of influencing factors and a decision. ${ }^{13}$ Extensive use was made of influence diagrams in the study of future societies for the WIPP Project.

\section{RECOMPOSITION}

The issue may be decomposed by the Project, by the experts, or through a cooperative effort. During discussions with the experts, the need for expert judgment and its intended use in performance assessment are explained. While the planned use of the results is discussed with the expert panel, the actual recomposition of the elicited information is the responsibility of the Project. This ensures that the recomposed information is compatible with the performance assessment.

The purpose of decomposition is to subdivide a complex problem into components that are easier to address. During the elicitations, the normative analyst attempts to elicit best estimates of the individual components, without considering what the recomposed result might be. With the Project as the party responsible for the recomposition, there is no opportunity, either intentional or unintentional, for panel members to alter individual component judgments in order to explicitly impact the eventual recomposition.

\section{SUMMARY}

Principles from the decision-analysis literature, modified by the experience of convening expert judgment panels, have allowed the WIPP Performance Assessment Department to develop an internal protocol for future expert panels. This protocol supports the production of quality results. The protocol would be appropriate for other repository programs in order to save time and effort in establishing their own protocols.

\section{REFERENCES}

1. "Environmental Standards for the Management and Disposal of Spent Nuclear Fuel, High-Level and Transuranic Radioactive Wastes; Final Rule, 40 CFR Part 191," U.S. EPA (Environmental Protection Agency), Federal Register, Vol. 50, no. 182, pp. 38066-38089, 1985.

2. "Environmental Radiation Protection Standards for the Management and Disposal of Spent Nuclear Fuel, High-Level and Transuranic Radioactive Wastes; Final Rule, 40 CFR Part 191," U.S. EPA (Environmental Protection Agency), Federal Register, Vol. 58, no. 242, pp. 66398-66416, 1993.

3. S. C. Hora, D. von Winterfeldt, and K. M. Trauth, Expert Judgment on Inadvertent Human Intrusion into the Waste Isolation Pilot Plant, SAND90-3063, Sandia National Laboratories, Albuquerque, NM, 1991. 
4. K. M. Trauth, S. C. Hora, and R. V. Guzowski, Expert Judgment on Markers to Deter Inadvertent Human Intrusion into the Waste Isolation Pilot Plant, SAND92-1382, Sandia National Laboratories, Albuquerque, NM, 1993.

5. K. M. Trauth, S. C. Hora, R. P. Rechard, and D. R. Anderson, The Use of Expert Judgment to Quantify Uncertainty in Solubility and Sorption Parameters for Waste Isolation Pilot Plant Performance Assessment, SAND92-0479, Sandia National Laboratories, Albuquerque, NM, 1992.

6. S. C. Hora and R. L. Iman, "Expert Opinion in Risk Analysis: The NUREG-1150 Methodology, " Nuclear Science and Engineering, Vol. 102, no. 4, pp. 323-331, 1989.

7. M. G. Morgan and M. Henrion, Uncertainty: $A$ Guide to Dealing with Uncertainty in Quantitative Risk and Policy Analysis, Cambridge University Press, Cambridge, Eng, 1991.

8. E. J. Bonano, S. C. Hora, R. L. Keeney, and D. von Winterfeldt, Elicitation and Use of Expert Judgment in Performance Assessment for High-Level Radioactive Waste Repositories, SAND89-1821, NUREG/CR-5411, Sandia National Laboratories, Albuquerque, NM, 1989.

9. R. M. Cooke, Experts in Uncertainty: Opinion and Subjective Probability in Science, Oxford University Press, Oxford, Eng., 1991.

10. R. P. Rechard, K. M. Trauth, and R. V. Guzowski, Quality Assurance Procedures for Parameter Selection and Use of Expert Judgment Panels Supporting Performance Assessments of the Waste Isolation Pilot Plant, SAND91-0429, Sandia National Laboratories, Albuquerque, NM, 1992.
11. $N R D C$ v. $E P A$, Nos. $85-1915,86-1096,86-1097,86-$ 1098 (1st Cir.) order dated Sept. 27, 1987.

12. R. G. Dosch and A. W. Lynch, Interaction of Radionuclides with Geomedia Associated with the Waste Isolation Pilot Plant (WIPP) Site in New Mexico, SAND78-0297, Sandia National Laboratories, Albuquerque, NM, 1978.

13. D. von Winterfeldt and W. Edwards, Decision Analysis and Behavioral Research, Cambridge University Press, Cambridge, Eng., 1986.

14. S. Lichtenstein and B. Fischhoff, "Training for Calibration," Organizational Behavior and Human Performance, Vol. 26, no. 2, pp. 149-171, 1980.

15. M. A. Meyer and J. M. Booker, Eliciting and Analyzing Expert Judgment: A Practical Guide, Academic Press, New York, NY, 1991.

16. S. C. Hora, J. A. Hora, and N. G. Dodd, "Assessment of Probability Distributions for Continuous Random Variables: A Comparison of the Bisection and Fixed Value Methods, "Organizational Behavior and Human Decision Processes, Vol. 51, no. 1, 133-155, 1992.

17. J. S. Armstrong, W. B. Denniston, and M. M. Gordon, "The Use of the Decomposition Principle in Making Judgments," Organizational Behavior and Human Performance, Vol. 14, no. 2, 257-263, 1975.

18. D. MacGregor, S. Lichtenstein, and P. Slovic, "Structuring Knowledge Retrieval: An Analysis of Decomposing Quantitative Judgments," Organizational Behavior and Human Decision Processes, Vol. 42, no. 3, pp. 303-323, 1988. 
19. R. D. Shachter, "Evaluating Influence Diagrams," Operations Research, Vol. 34, no. 6, pp. 871-872, 1986. 


\section{PERFORMANCE ASSESSMENT DISTRIBUTION LIST}

(Send Distribution list changes to F. Puffer, Tech Reps. Inc., 5000 Marble NE, Suite 200 Albuquerque, NM 87110)

\section{Federal Agencies}

US Department of Energy (6)

Office of Civilian Radioactive Waste

Management

Attn: Deputy Director, RW-2

Associate Director, RW-10/50

Office of Program and Resources

Management

Office of Contract Business

Management

Director, RW-22, Analysis and

Verification Division

Associate Director, RW-30

Office of Systems and Compliance

Associate Director, RW-40

Office of Storage and

Transportation

Director, RW-4/5

Office of Strategic Planning and

International Programs Office of

External Relations

Forrestal Building

Washington, DC 20585

US Department of Energy

Albuquerque Operations Office

Attn: National Atomic Museum Library

PO Box 5400

Albuquerque, NM 87185

US Department of Energy (2)

Office of Environmental Restoration and

Waste Management

Attn: Director, EM-1

C. Frank, EM-50

Washington, DC 20585

US Department of Energy (3)

Office of Environmental Restoration and

Waste Management

Attn: M. Frei, EM-34 / Trevion II

Director, Waste Management Projects

Washington, DC 20585-0002
US Department of Energy

Office of Environmental Restoration and

Waste Management

Attn: J. Lytle, EM-30 / Trevion II

Washington, DC 20585-0002

US Department of Energy

Office of Environmental Restoration and Waste Management

Attn: S. Schneider, EM-342

Trevion II

Washington, DC 20585-0002

US Department of Energy (3)

WIPP Task Force

Attn: G.H. Daly

S. Fucigna

B. Bower

12800 Middlebrook Rd., Suite 400

Germantown, MD 20874

US Department of Energy (4)

Office of Environment, Safety and

Health

Attn: R.P. Berube, EH-20

C. Borgstrom, EH-25

R. Pelletier, EH-231

K. Taimi, EH-232

Washington, DC 20585

US Department of Energy (6)

WIPP Project Integration Office

Attn: S. Alcorn

W.J. Arthur III

J. Coffey

L.W. Gage

P.J. Higgins

D.A. Olona

PO Box 5400

Albuquerque, NM 87115-5400

Dist-1 
US Department of Energy (2)

WIPP Project Integration Satellite Office

Attn: R. Batra

R. Becker

PO Box 3090, Mail Stop 525

Carlsbad, NM 88221-3090

US Department of Energy (10)

Carlsbad Operations Center Attn: A. Hunt

(4)

$$
\begin{aligned}
& \text { V. Daub (4) } \\
& \text { L. Lippis } \\
& \text { K. Hunter }
\end{aligned}
$$

PO Box 3090

Carlsbad, NM 88221-3090

US Department of Energy

Research \& Waste Management Division

Attn: Director

PO Box E

Oak Ridge, TN 37831

US Department of Energy (2)

Idaho Operations Office

Fuel Processing and Waste Management

Division

785 DOE Place

Idaho Falls, ID 83402

US Department of Energy

Savannah River Operations Office

Defense Waste Processing

Facility Project Office

Attn: W.D. Pearson

PO Box A

Aiken, SC 29802

US Department of Energy (2)

Richland Operations Office

Waste Management Division

Attn: Rudy F. Guercia

825 Jadwin Avenue

PO Box 550

Richland, WA 99352
US Department of Energy

Office of Geologic Disposal

Yucca Mountain Project Office

Attn: Associate Director, RW-20

PO Box 98608

Las Vegas, NV 89193-8608

US Department of Energy (3)

Nevada Operations Office

Attn: J.R. Boland

D. Livingston

P.K. Fitzsimmons

2753 S. Highland Drive

Las Vegas, NV 89183-8518

US Department of Energy (2)

Technical Information Center

PO Box 62

Oak Ridge, TN 37831

US Department of Energy (2)

Chicago Operations Office

Attn: J.C. Haugen

9800 South Cass Avenue

Argonne, IL 60439

US Department of Energy (3)

Rocky Flats Area Office

Attn: W.C. Rask

G. Huffman

T. Lukow

PO Box 928

Golden, CO 80402-0928

US Department of Energy

Los Alamos Area Office

528 35th Street

Los Alamos, NM 87544

US Department of Energy

Dayton Area Office

Attn: R. Grandfield

PO Box 66

Miamisburg, $\mathrm{OH}$ 45343-0066 
US Bureau of Land Management

Carlsbad Office

101 E. Mermod

Carlsbad, NM 88220

US Bureau of Land Management

New Mexico State Office

PO Box 1449

Santa Fe, NM 87507

US Environmental Protection

Agency (2)

Radiation Protection Programs

Attn: M. Oge

ANR-460

Washington, DC 20460

US Environmental Protection

Agency, Region 6

tn: C. Byrum, 6T-ET

1445 Ross Ave.

Dallas, TX 75202

US Geological Survey (2)

Water Resources Division

Attn: C. Peters

4501 Indian School NE

Suite 200

Albuquerque, NM 87110

US Nuclear Regulatory Commission

Division of Waste Management

Attn: H. Marson

Mail Stop 4-H-3

Washington, DC 20555

US Nuclear Regulatory Commission (4) Advisory Committee on Nuclear Waste Attn: D. Moeller M.J. Steindler

P.W. Pomeroy

W.J. Hinze

7920 Norfolk Ave.

Bethesda, MD 20814
Defense Nuclear Facilities Safety Board

Attn: D. Winters

625 Indiana Ave. NW

Suite 700

Washington, DC 20004

Nuclear Waste Technical Review Board

Attn: Library (2)

1100 Wilson Blvd.

Suite 910

Arlington, VA 22209-2297

\section{State Agencies}

New Mexico Bureau of Mines and Mineral Resources

Socorro, NM 87801

New Mexico Energy, Minerals and

Natural Resources Department

Attn: Librarian

2040 South Pacheco

Santa Fe, NM 87505

New Mexico Energy, Minerals and

Natural Resources Department

New Mexico Radioactive Task Force (2)

(Governor's WIPP Task Force)

Attn: A. Lockwood, Chairman

C. Wentz, Policy Analyst

2040 South Pacheco

Santa Fe, NM 87505

Bob Forrest

Mayor, City of Carlsbad

PO Box 1569

Carlsbad, NM 88221

Carlsbad Department of Development

Executive Director

Attn: C. Bernard

PO Box 1090

Carlsbad, NM 88221 
New Mexico Environment Department

Secretary of the Environment (3)

Attn: J. Espinosa

PO Box 968

1190 St. Francis Drive

Santa Fe, NM 87503-0968

New Mexico Environment Department

Attn: P. McCasland

WIPP Project Site Office

PO Box 3090

Carlsbad, NM 88221-3090

New Mexico State Engineer's Office

Attn: M. Chudnoff

PO Box 25102

Santa Fe, NM 87504-5102

Environmental Evaluation Group (5)

Attn: R. Neill

7007 Wyoming Blvd. NE, Suite F-2

Albuquerque, NM 87109

\section{Advisory Committee on Nuclear Facility Safety}

John F. Ahearne

Executive Director, Sigma Xi

99 Alexander Drive

Research Triangle Park, NC 27709

James E. Martin

109 Observatory Road

Ann Arbor, MI 48109

WIPP Committee, National Research

Council's Board on Radioactive Waste Management

National Research Council (2)

Board on Radioactive Waste Management

Attn: C.A. Anderson

I.B. Alterman

2101 Constitution Ave. NW

Harris Bldg. HA 456

Washington, DC 20418
Howard Adler

Oxyrase, Inc.

11020 Solway School Rd.

Knoxville, TN 37931

John O. Blomeke

3833 Sandy Shore Drive

Lenoir City, TN 37771-9803

John D. Bredehoeft

Western Region Hydrologist

Water Resources Division

US Geological Survey (M/S 439)

345 Middlefield Road

Menlo Park, CA 94025

Fred M. Ernsberger

1325 NW Tenth Ave.

Gainsville, FL 32605

Rodney C. Ewing

Department of Geology

University of New Mexico

Albuquerque, NM 87131

Charles Fairhurst

Department of Civil and Mineral

Engineering

University of Minnesota

500 Pillsbury Dr. SE

Minneapolis, MN 55455-0220

B. John Garrick

PLG, Incorporated

4590 MacArthur Blvd., Suite 400

Newport Beach, CA 92660-2027

Leonard F. Konikow

US Geological Survey

431 National Center

Reston, VA 22092

Jeremiah O'Driscoll

Jody, Incorporated

505 Valley Hill Drive

Atlanta, GA 30350 
Christopher G. Whipple

ICF Kaiser Engineers

1800 Harrison St. 7th Floor

Oakland, CA 94612-3430

Thomas A. Zordan

Zordan Associates, Inc.

3807 Edinburg Dr.

Murrysville, PA 15668

\section{Performance Assessment Peer Review} Panel

G. Ross Heath

College of Ocean \& Fishery Sciences

University of Washington

583 Henderson Hall, HN-15

Seattle, WA 98195

Thomas H. Pigford

Department of Nuclear Engineering

4159 Etcheverry Hall

University of California

Berkeley, CA 94720

Thomas A. Cotton

JK Research Associates, Inc.

4429 Butterworth Place NW

Washington, DC 20016

Robert J. Budnitz

President, Future Resources Associates,

Inc.

2000 Center Street

Suite 418

Berkeley, CA 94704

C. John Mann

Department of Geology

245 Natural History Bldg.

1301 West Green Street

University of Illinois

Urbana, IL 61801
Frank W. Schwartz

Department of Geology and Mineralogy

The Ohio State University

Scott Hall

1090 Carmack Rd.

Columbus, OH 43210

\section{National Laboratories}

Argonne National Laboratory (2)

Attn: A. Smith

D. Tomasko

9700 South Cass, Bldg. 201

Argonne, IL 60439

Battelle Pacific Northwest

Laboratory (2)

Attn: S. Bates

R.E. Westerman

MSIN P8-44

Battelle Boulevard

Richland, WA 99352

Idaho National Laboratory (2)

Westinghouse-Idaho Nuclear Co.

Attn: H. Loo

R. Klingler

Mail Stop 3422

P.O. Box 4000

Idaho Falls, ID 83415-3422

Los Alamos National Laboratory (5)

Attn: B. Erdal, INC-12

M. Ennis, HS-12

Mail Stop J900

S. Kosiewicz, EM-7

Mail Stop J595

L. Soholt, EM-13

Mail Stop M992

J. Wenzel, HS-12

Mail Stop K482

PO Box 1663

Los Alamos, NM 87545 
Oak Ridge National Laboratory

Transuranic Waste Manager

Attn: D.W. Turner

Bldg. 3047

PO Box 2008

Oak Ridge, TN 37831-6060

Pacific Northwest Laboratory

Attn: B. Kennedy

PO Box 999

Richland, WA 99352

Westinghouse-Savannah River

Technology

Center (4)

Attn: N. Bibler

J.R. Harbour

M.J. Plodinec

G.G. Wicks

Aiken, SC 29802

\section{Corporations/Members of the Public}

Battelle Memorial Institute

Attn: R. Root

J. Kircher

505 Marquette NW, Suite 1

Albuquerque, NM 87102

Benchmark Environmental Corp.

Attn: C. Frederickson

4501 Indian School NE, Suite 105

Albuquerque, NM 87110

Beta Corporation Int.

Attn: E. Bonano

6613 Esther NE

Albuquerque, NM 87109

City of Albuquerque

Public Works Department

Utility Planning Division

Attn: W.K. Summers

PO Box 1293

Albuquerque, NM 87103
Deuel and Associates, Inc.

Attn: R.W. Prindle

7208 Jefferson NE

Albuquerque, NM 87109

Disposal Safety, Inc.

Attn: B. Ross

1660 L Street NW, Suite 314

Washington, DC 20036

Ecodynamics (2)

Attn: P. Roache

R. Blaine

PO Box 9229

Albuquerque, NM 87119-9229

EG \& G Idaho (3)

1955 Fremont Street

Attn: C. Atwood

C. Hertzler

T.I. Clements

Idaho Falls, ID 83415

Geomatrix

Attn: K. Coppersmith

100 Pine St., Suite 1000

San Francisco, CA 94111

Golder Associates, Inc.

Attn: R. Kossik

4104 148th Avenue NE

Redmond, WA 98052

John Hart and Associates, P.A.

Attn: J.S. Hart

2815 Candelaria Road NW

Albuquerque, NM 87107

John Hart and Associates, P.A.

Attn: K. Lickliter

400-C 8th St. NW

Tacoma, WA 98439

INTERA, Inc.

Attn: A.M. LaVenue

1650 University Blvd. NE, Suite 300

Albuquerque, NM 87102 
INTERA, Inc.

Attn: J.F. Pickens

6850 Austin Center Blvd., Suite 300

Austin, TX 78731

INTERA, Inc.

Attn: W. Stensrud

PO Box 2123

Carlsbad, NM 88221

INTERA, Inc.

Attn: W. Nelson

101 Convention Center Dr.

Suite 540

Las Vegas, NV 89109

IT Corporation (2)

Attn: R.F. McKinney

J. Myers

Regional Office, Suite 700

5301 Central Avenue NE

Albuquerque, NM 87108

Lawrence Berkeley Laboratory

Attn: J. Long

Building $50 \mathrm{E}$

Berkeley, CA 94720

MAC Technical Services Co.

Attn: D.K. Duncan

8418 Zuni Road SE, Suite 200

Albuquerque, NM 87108

Newman and Holtzinger

Attn: C. Mallon

1615 L Street NW, Suite 1000

Washington, DC 20036

RE/SPEC, Inc. (2)

Attn: W. Coons

4775 Indian School NE, Suite 300

Albuquerque, NM 87110

RE/SPEC, Inc.

Attn: J.L. Ratigan

PO Box 725

Rapid City, SD 57709
Reynolds Electric and Engineering

Company, Inc.

Attn: E.W. Kendall

Building 790

Warehouse Row

PO Box 98521

Las Vegas, NV 89193-8521

SAIC

Attn: H.R. Pratt

10260 Campus Point Drive

San Diego, CA 92121

SAIC

Attn: C.G. Pflum

101 Convention Center Dr.

Las Vegas, NV 89109

SAIC (3)

Attn: M. Davis

R. Guzowski

J. Tollison

2109 Air Park Road SE

Albuquerque, NM 87106

SAIC (2)

Attn: J. Young

D. Lester

18706 North Creek Parkway, Suite 110

Bothell, WA 98011

Southwest Research Institute

Nuclear Waste Regulatory Analysis (2)

Attn: P.K. Nair

6220 Culebra Road

San Antonio, TX 78228-0510

Systems, Science, and Software (2)

Attn: E. Peterson

P. Lagus

Box 1620

La Jolla, CA 92038

TASC

Attn: S.G. Oston

55 Walkers Brook Drive

Reading, MA 01867 
Tech Reps, Inc. (6)

Attn: J. Chapman

C. Crawford

D. Marchand

T. Peterson

J. Stikar

D. Scott

5000 Marble NE, Suite 222

Albuquerque, NM 87110

Tolan, Beeson \& Associates

Attn: T.L. Tolan

2320 W. 15th Avenue

Kennewick, WA 99337

TRW Environmental Safety Systems (2)

Attn: I. Sacks, Suite 800

L. Wildman, Suite 1300

2650 Park Tower Drive

Vienna, VA 22180-7306

Sanford Cohen and Associates

Attn: J. Channell

7101 Carriage Rd NE

Albuquerque, NM 87109

Westinghouse Electric Corporation (5)

Attn: Library

C. Cox

L. Fitch

B.A. Howard

R.F. Kehrman

PO Box 2078

Carlsbad, NM 88221

Westinghouse Hanford Company

Attn: D.E. Wood, MSIN HO-32

PO Box 1970

Richland, WA 99352

Western Water Consultants

Attn: P.A. Rechard

PO Box 4128

Laramie, WY 82071
Western Water Consultants

Attn: D. Fritz

1949 Sugarland Drive \#134

Sheridan, WY 82801-5720

P. Drez

8816 Cherry Hills Road NE

Albuquerque, NM 87111

David Lechel

9600 Allende Rd. NE

Albuquerque, NM 87109

C.A. Marchese

PO Box 21790

Albuquerque, NM 87154

Arend Meijer

3821 Anderson SE

Albuquerque, NM 87108

D.W. Powers

Star Route Box 87

Anthony, TX 79821

Shirley Thieda

PO Box 2109, RR1

Bernalillo, NM 87004

Jack Urich

c/o CARD

144 Harvard SE

Albuquerque, NM 87106

\section{Universities}

University of California

Mechanical, Aerospace, and

Nuclear Engineering Department (2)

Attn: W. Kastenberg

D. Browne

5532 Boelter Hall

Los Angeles, CA 90024 
University of California

Engineering and Applied Science

Attn: D. Okrent

48-121A Engineering IV

Los Angeles, CA 90024-1597

University of California

Mine Engineering Department

Rock Mechanics Engineering

Attn: N. Cook

Berkeley, CA 94720

University of Hawaii at Hilo

Business Administration

Attn: S. Hora

Hilo, HI 96720-4091

University of Illinois

Department of Geology

Attn: C. Bethke

1301 W. Green St.

Urbana, IL 61801

University of New Mexico

Geology Department

Attn: Library

Albuquerque, NM 87131

University of New Mexico

Research Administration

Attn: H. Schreyer

102 Scholes Hall

Albuquerque, NM 87131

University of Wyoming

Department of Civil Engineering

Attn: V.R. Hasfurther

Laramie, WY 82071

University of Wyoming

Department of Geology

Attn: J.I. Drever

Laramie, WY 82071

\section{Libraries}

Thomas Brannigan Library

Attn: D. Dresp

106 W. Hadley St.

Las Cruces, NM 88001

New Mexico State Library

Attn: N. McCallan

325 Don Gaspar

Santa Fe, NM 87503

New Mexico Tech

Martin Speere Memorial Library

Campus Street

Socorro, NM 87810

New Mexico Junior College

Pannell Library

Attn: R. Hill

Lovington Highway

Hobbs, NM 88240

Carlsbad Municipal Library

WIPP Public Reading Room

Attn: L. Hubbard

101 S. Halagueno St.

Carlsbad, NM 88220

University of New Mexico

Zimmerman Library

Government Publications Department

Albuquerque, NM 87131

\section{NEA/Performance Assessment Advisory Group (PAAG)}

P. Duerden

ANSTO

Lucas Heights Research Laboratories

Private Mail Bag No. 1

Menai, NSW 2234

AUSTRALIA 
Gordon S. Linsley

Division of Nuclear Fuel Cycle and Waste

Management

International Atomic Energy Agency

PO Box 100

A-1400 Vienna, AUSTRIA

Nicolo Cadelli

Commission of European Communities

200, Rue de la Loi

B-1049 Brussels, BELGIUM

R. Heremans

Organisme Nationale des Déchets

Radioactifs et des Matiéres Fissiles

(ONDRAF)

Place Madou 1, Boitec 24/25

B-1030 Brussels, BELGIUM

J. Marivoet

Centre d'Etudes de l'Energie Nucléaire

(CEN/SCK)

Boeretang 200

B-2400 Mol, BELGIUM

P. Conlon

Waste Management Division

Atomic Energy Control Board (AECB)

PO Box 1046

Ottawa, Ontario KIP 559, CANADA

A.G. Wikjord

Manager, Environmental and Safety

Assessment Branch, AECL

Whiteshell Laboratories

Pinawa, Manitoba ROE 1LO, CANADA

Teollisuuden Voima Oy (TVO) (2)

Attn: Timo Äikäs

Jukka-Pekka Salo

Annankatu $42 \mathrm{C}$

SF-00100 Helsinki Suomi, FINLAND
Timo Vieno

Technical Research Centre of Finland

(VTT)

Nuclear Energy Laboratory

PO Box 208

SF-02151 Espoo, FINLAND

Division de la Sécurité et de la Protection de 1'Environment (DSPE)

Commissariat á l'Energie Atomique

Agence Nationale pour la Gestion des

Déchets Radioactifs (ANDRA)

Attn: Gérald Ouzounian

M. Claude Ringeard

Route du Panorama Robert Schuman

B. P. No. 38

F-92266 Fontenay-aux-Roses Cedex

FRANCE

Claudio Pescatore

Division of Radiation Protection and

Waste Management

OECD Nuclear Energy Agency

38, Boulevard Suchet

F-75016 Paris, FRANCE

M. Dominique Greneche

Commissariat á l'Energie Atomique

IPSN/DAS/SASICC/SAED

B.P. No. 6

F-92265 Fontenay-aux-Roses Cedex

FRANCE

Robert Fabriol

Bureau de Recherches Géologiques et

Miniéres (BRGM)

B.P. 6009

45060 Orléans Cedex 2

FRANCE

P. Bogorinski

Gesellschaft für Reaktorsicherheit (GRS)

MBH

Schwertnergasse 1

D-5000 Köln 1, GERMANY 
R. Storck

GSF - Institut für Tieflagerung

Theodor-Heuss-Strabe 4

D-3300 Braunschweig, GERMANY

Ferrucio Gera

ISMES S.p.A

Via del Crociferi 44

I-00187 Rome, ITALY

Hiroyuki Umeki

Isolation System Research Program

Radioactive Waste Management Project

Power Reactor and Nuclear Fuel

Development Corporation (PNC)

1-9-13, Akasaka, Minato-ku

Tokyo 107, JAPAN

Tönis Papp

Swedish Nuclear Fuel and Waste

Management Co.

Box 5864

S 10248 Stockholm

SWEDEN

Conny Hägg

Swedish Radiation Protection Institute

(SSI)

Box 60204

S-104 01 Stockholm, SWEDEN

J. Hadermann

Paul Scherrer Institute

Waste Management Programme

CH-5232 Villigen PSI

SWITZERLAND

J. Vigfusson

HSK-Swiss Nuclear Safety Inspectorate

Federal Office of Energy

CH-5232 Villigen-HSK

SWITZERLAND
D.E. Billington

Departmental Manager-Assessment

Studies

Radwaste Disposal R\&D Division

AEA Decommissioning \& Radwaste

Harwell Laboratory, B60

Didcot Oxfordshire OX11 ORA

UNITED KINGDOM

P. Grimwood

Waste Management Unit, BNFL

Sellafield

Seascale, Cumbria CA20 1PG

UNITED KINGDOM

Alan J. Hooper

UK Nirex Ltd

Curie Avenue

Harwell, Didcot

Oxfordshire, OX11 ORH

UNITED KINGDOM

Jerry M. Boak

Yucca Mountain Project Office

US Department of Energy

PO Box 98608

Las Vegas, NV 89193

Seth M. Coplan (Chairman)

US Nuclear Regulatory Commission

Division of HLW Management

Mail Stop 4-H-3

Washington, DC 20555

A.E. Van Luik

INTERA/M\&O

The Valley Bank Center

101 Convention Center Dr.

Las Vegas, NV 89109 
NEA/Probabilistic System Assessment Group (PSAG)

Shaheed Hossain

Division of Nuclear Fuel Cycle and Waste Management

International Atomic Energy Agency

Wagramerstrasse 5

PO Box 100

A-1400 Vienna, AUSTRIA

Eduard Hofer

Gesellschaft für Reaktorsicherheit (GRS)

$\mathrm{MBH}$

Forschungsgelände

D-8046 Garching, GERMANY

Andrea Saltelli

Commission of European Communities

Joint Resarch Centre of Ispra

I-21020 Ispra (Varese), ITALY

Alejandro Alonso

Cátedra de Tecnología Nuclear

E.T.S. de Ingenieros Industriales

José Gutiérrez Abascal, 2

E-28006 Madrid, SPAIN

ENRESA (2)

Attn: M. A. Cuñado

F. J. Elorza

Calle Emilio Vargas, 7

E-28043 Madrid, SPAIN

Pedro Prado

CIEMAT

Instituto de Tecnología Nuclear

Avenida Complutense, 22

E-28040 Madrid, SPAIN

Nils A. Kjellbert

Swedish Nuclear Fuel and Waste

Management

Company (SKB)

Box 5864

S-102 48 Stockholm, SWEDEN
Björn Cronhjort

Royal Institute of Technology

Automatic Control

S-100 44 Stockholm, SWEDEN

Richard A. Klos

Paul-Scherrer Institute (PSI)

CH-5232 Villingen PSI, SWITZERLAND

Nationale Genossenschaft für die

Lagerung Radioaktiver Abfälle (2)

Attn: C. McCombie

F. Van Dorp

Hardstrasse 73

CH-5430 Wettingen, SWITZERLAND

N. A. Chapman

Intera Information Technologies

Park View House, 14B Burton Street

Melton Mowbray

Leicestershire LE13 1AE

UNITED KINGDOM

Daniel A. Galson

Galson Sciences Ltd.

5 Grosvenor House

Melton Road

Oakham

Rutland LE15 6AX

UNITED KINGDOM

David P. Hodgkinson

Intera Information Technologies

45 Station Road, Chiltern House

Henley-on-Thames

Oxfordshire RG9 1AT

UNITED KINGDOM

Brian G.J. Thompson

Department of the Environment: Her

Majesty's Inspectorate of Pollution

Room A5.33, Romney House

43 Marsham Street

London SW1P 2PY, UNITED

KINGDOM 
Intera Information Technologies

Attn: M.J.Apted

3609 South Wadsworth Blvd.

Denver, CO 80235

US Nuclear Regulatory Commission (2)

Attn: R. Codell

N. Eisenberg

Mail Stop 4-H-3

Washington, DC 20555

Battelle Pacific Northwest Laboratories

Attn: P.W. Eslinger

MS K2-32

PO Box 999

Richland, WA 99352

Center for Nuclear Waste Regulatory

Analysis (CNWRA)

Southwest Research Institute

Attn: B. Sagar

PO Drawer 28510

6220 Culebra Road

San Antonio, TX 78284

\section{Geostatistics Expert Working Group (GXG)}

Rafael L. Bras

R.L. Bras Consulting Engineers

44 Percy Road

Lexington, MA 02173

Jesus Carrera

Universidad Politècnica de Cataluña

E.T.S.I. Caminos

Jordi, Girona 31

E-08034 Barcelona, SPAIN

Gedeon Dagan

Department of Fluid Mechanics and Heat

Transfer

Tel Aviv University

PO Box 39040

Ramat Aviv, Tel Aviv 69978

ISRAEL
Ghislain de Marsily (GXG Chairman)

University Pierre et Marie Curie

Laboratorie de Geologie Applique

4, Place Jussieu

T. $26-5^{\mathrm{e}}$ etage

75252 Paris Cedex 05

FRANCE

Alain Galli

Centre de Geostatistique

Ecole des Mines de Paris

35 Rue St. Honore

77035 Fontainebleau, FRANCE

Christian Ravenne

Geology and Geochemistry Division

Institut Francais du Pétrole

$1 \& 4$, Av. de Bois-Préau B.P. 311

92506 Rueil Malmaison Cedex

FRANCE

Peter Grindrod

INTERA Information Technologies Ltd,

Chiltern House

45 Station Road

Henley-on-Thames

Oxfordshire, RG9 1AT, UNITED

KINGDOM

Alan Gutjahr

Department of Mathematics

NM Institute of Mining and Technology

Socorro, NM 87801

C. Peter Jackson

Harwell Laboratory

Theoretical Studies Department

Radwaste Disposal Division

Bldg. 424.4

Oxfordshire Didcot Oxon OX11 ORA

UNITED KINDGOM

Rae Mackay

Department of Civil Engineering

University of Newcastle Upon Tyne

Newcastle Upon Tyne NE1 7RU

UNITED KINGDOM 
Steve Gorelick

Department of Applied Earth Sciences

Stanford University

Stanford, CA 94305-2225

Peter Kitanidis

60 Peter Coutts Circle

Stanford, CA 94305

Dennis McLaughlin

Parsons Laboratory

Room 48-209

Department of Civil Engineering

Massachusetts Institute of Technology

Cambridge, MA 02139

Shlomo P. Neuman

College of Engineering and Mines

Hydrology and Water Resources Dept.

University of Arizona

Tucson, AZ 85721

Yoram Rubin

Department of Civil Engineering

University of California

Berkeley, CA 94720

\section{Foreign Addresses}

Studiecentrum Voor Kernenergie

Centre D'Energie Nucleaire

Attn: A. Bonne

SCK/CEN

Boeretang 200

B-2400 Mol, BELGIUM

Atomic Energy of Canada, Ltd. (3)

Whiteshell Laboratories

Attn: M.E. Stevens

B.W. Goodwin

D. Wushke

Pinewa, Manitoba ROE 1LO, CANADA

Juhani Vira

Teollisuuden Voima Oy (TVO)

Annankatu $42 \mathrm{C}$

SF-00100 Helsinki Suomi

FINLAND
Jean-Pierre Olivier

OECD Nuclear Energy Agency (2)

38, Boulevard Suchet

F-75016 Paris, FRANCE

D. Alexandre, Deputy Director

ANDRA

31 Rue de la Federation

75015 Paris, FRANCE

Claude Sombret

Centre D'Etudes Nucleaires

De La Vallee Rhone

CEN/VALRHO

S.D.H.A. B.P. 171

30205 Bagnols-Sur-Ceze, FRANCE

Commissariat a L'Energie Atomique

Attn: D. Alexandre

Centre d'Études de Cadarache

13108 Saint Paul Lez Durance Cedex

FRANCE

Bundesministerium für Forschung und

Technologie

Postfach 200706

5300 Bonn 2, GERMANY

Bundesanstalt für Geowissenschaften und Rohstoffe

Attn: M. Langer

Postfach 510153

D-30631 Hannover, GERMANY

Gesellschaft für Anlagen und

Reaktorsicherheit (GRS)

Attn: B. Baltes

W. Muller

Schwertnergasse 1

D-50667 Cologne, GERMANY

Institut fur Tieflagerung (2)

Attn: K. Kuhn

Theodor-Heuss-Strasse 4

D-3300 Braunschweig

GERMANY 
Physikalisch-Technische

Bundesanstalt

Attn: P. Brenneke

Postfach 3345

D-3300 Braunschweig

GERMANY

Shingo Tashiro

Japan Atomic Energy Research Institute

Tokai-Mura, Ibaraki-Ken

319-11, JAPAN

Netherlands Energy Research Foundation (ECN)

Attn: L.H. Vons

3 Westerduinweg

PO Box 1

1755 ZG Petten

THE NETHERLANDS

Johan Andersson

Swedish Nuclear Power Inspectorate

Statens Kärnkraftinspektion (SKI)

Box 27106

S-102 52 Stockholm

SWEDEN

Fred Karlsson

Svensk Kärnbränsleforsorjning $\mathrm{AB}$

Project KBS

Box 5864

S-102 48 Stockholm

SWEDEN

Nationale Genossenschaft für die

Lagerung Radioaktiver Abfälle (2)

Attn: S. Vomvoris

P. Zuidema

Hardstrasse 73

CH-5430 Wettingen

SWITZERLAND

AEA Technology

Attn: J.E. Tinson

B4244 Harwell Laboratory

Didcot, Oxfordshire OX11 ORA

UNITED KINGDOM
AEA Technology

Attn: J.H. Rees

D5W/29 Culham Laboratory

Abington

Oxfordshire OX14 3DB

UNITED KINGDOM

AEA Technology

Attn: W.R. Rodwell

O44/A31 Winfrith Technical Centre

Dorchester

Dorset DT2 8DH, UNITED KINGDOM

D.R. Knowles

British Nuclear Fuels, plc

Risley, Warrington

Cheshire WA3 6AS, 1002607

UNITED KINGDOM

\section{Internal}

MS Org.

01010001

01020002

08271502

08271511

01274511

07246000

13246115

13246115

07506118

13206119

13206119

13226121

13226121

13376300

13356302

13956700

13356303

13356305

13456307

13416306

13266312

13266313

13456331

13306352

13286342

13286342
A. Narath

O.E. Jones

P.J. Hommert

D.K. Gartling

D.P. Garber

D.L. Hartley

P.B. Davies

R.L. Beauheim

H.R. Westrich

E.J. Nowak

Staff (14)

J.R. Tillerson

Staff (7)

D.E. Ellis

L.E. Shephard

S.Y. Pickering

W.D. Weart

S.A. Goldstein

A.R. Lappin

A.L. Stevens

F.W. Bingham

L.S. Costin

P.A. Davis

WIPP Central Files (100)

D.R. Anderson

Staff (20) 


$\begin{array}{lll}13956743 & \text { V.H. Slaboszewicz } \\ 13956743 & \text { Staff (3) } \\ 134166345 & \text { R.C. Lincoln } \\ 13416345 & \text { Staff (9) } \\ 134166347 & \text { D.R. Schafer } \\ 13416648 & \text { J.T. Holmes } \\ 13416348 & \text { Staff (4) } \\ 134366351 & \text { R.E. Thompson } \\ 13306352 & \text { G. Gerstner-Miller (2) } \\ 07366400 & \text { N.R. Ortiz } \\ 07466613 & \text { R.M. Cranwell } \\ 07466613 & \text { R.L. Iman } \\ 07466613 & \text { C. Leigh } \\ 07276622 & \text { M.S.Y. Chu } \\ 07186641 & \text { R.E. Luna, Acting } \\ 089913414 & \text { Technical Library (5) } \\ 061913416 & \text { Technical Publications } \\ 01007613-2 & \text { Document Processing } \\ & \text { for DOE/OSTI (10) }\end{array}$

9018 8523-2 Central Technical Files 